\title{
Knowledge, Attitude, and Practices (KAP) on Community- Oriented Policing in Malaysian Neighbourhoods
}

Siti Shazwani Ahmad Suhaimi, Nur Shuhamin Nazuri, Nik Ahmad Sufian Burhan, Abdul Razak Abdul Rahman, Hanina H. Hamsan

To Link this Article: http://dx.doi.org/10.6007/IJARBSS/v11-i12/11795

DOI:10.6007/IJARBSS/v11-i12/11795

Received: 08 October 2021, Revised: 10 November 2021, Accepted: 28 November 2021

Published Online: 16 December 2021

In-Text Citation: (Suhaimi et al., 2021)

To Cite this Article: Suhaimi, S. S. A., Nazuri, N. S., Burhan, N. A. S., Rahman, A. R. A., \& Hamsan, H. H. (2021). Knowledge, Attitude, and Practices (KAP) on Community-Oriented Policing in Malaysian Neighbourhoods. International Journal of Academic Research in Business and Social Sciences, 11(12), 517-526.

Copyright: (c) 2021 The Author(s)

Published by Human Resource Management Academic Research Society (www.hrmars.com)

This article is published under the Creative Commons Attribution (CC BY 4.0) license. Anyone may reproduce, distribute, translate and create derivative works of this article (for both commercial and non0-commercial purposes), subject to full attribution to the original publication and authors. The full terms of this license may be seen

at: http://creativecommons.org/licences/by/4.0/legalcode

Vol. 11, No. 12, 2021, Pg. 517 - 526

Full Terms \& Conditions of access and use can be found at http://hrmars.com/index.php/pages/detail/publication-ethics 


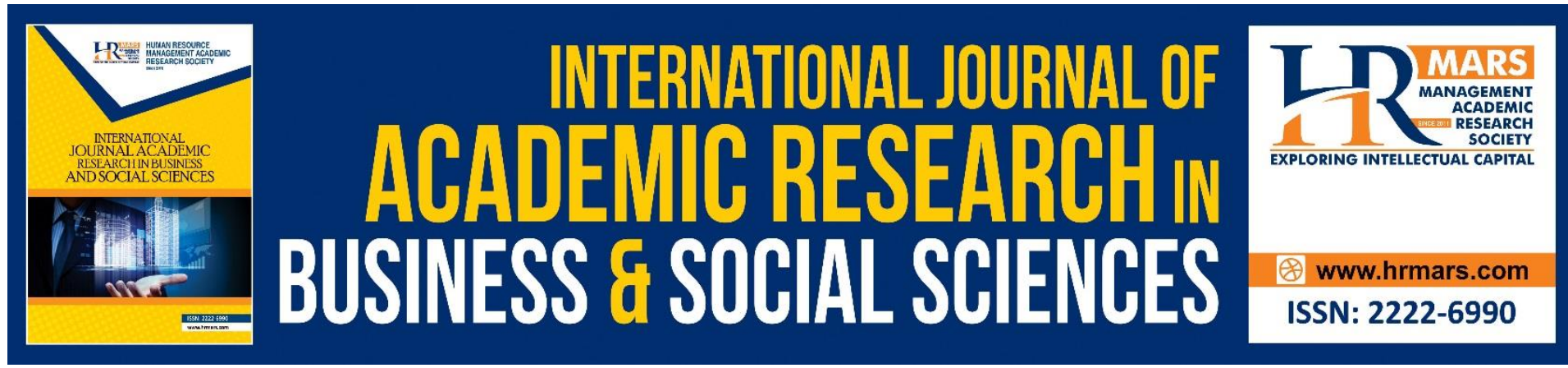

\title{
Knowledge, Attitude, and Practices (KAP) on Community-Oriented Policing in Malaysian Neighbourhoods
}

\author{
Siti Shazwani Ahmad Suhaimi ${ }^{1}$, Nur Shuhamin Nazuri ${ }^{1}$, Nik \\ Ahmad Sufian Burhan ${ }^{1,2}$, Abdul Razak Abdul Rahman ${ }^{1}$, Hanina \\ H. Hamsan ${ }^{1,2}$ \\ ${ }^{1}$ Department of Social and Development Sciences, Faculty of Human Ecology, Universiti \\ Putra Malaysia, ${ }^{2}$ Institute for Social Science Studies (IPSAS), Universiti Putra Malaysia \\ Email: nikahmadsufian@upm.edu.my
}

\begin{abstract}
The concept of community policing is highlighted as an effort to achieve enhanced level of safety and security that can be sustained through community involvement. In Malaysia, the community-oriented policing has been implemented across neighbourhoods since 1968 under the supervision of the Royal Malaysia Police (PDRM). However, does the local community these days understand the concept and practice? Thus, the current study attempted to determine the levels of knowledge, attitude, and practices, or simply referred to as KAP among local communities that have been exercising community policing. Through a quantitative survey in five major zones in Malaysia, this study confirmed equally high levels of knowledge on and attitude towards community policing, with scores of around 4 based on Likert scale of 1-5. On the other hand, the score was slightly lower for practices, which was around 3.5. This study concluded that in general, the local communities have exercised community policing despite living in busy urban environments. Several policy implications were proposed to ensure the sustainability of community-oriented policing while fostering social cohesion in neighbourhoods in Malaysia.
\end{abstract}

Keywords: Community Policing, Community Development, KAP Study, Safety, Community Participation

\section{Background}

In 1967, Tun Salleh Ismail (Second Inspector General of Police) sparked the idea of the concept of assimilating the police with the local community as a proactive preventive measure. The Salleh system is an effort to increase the effectiveness of crime eradication actions by involving the public directly (Aslie \& Ibrahim, 1984; Ismail et al., 2004). The implementation of the Salleh System applies the concept of community-oriented policing, or simply termed as community policing. The system is distinguished based on five objectives specifically; (i) Promotion of public trust where police can be witnessed on the streets; (ii) Deliver prompt assistance to the people after getting complaints and information; (iii) Ease the process of 
information distribution by restructuring and refining the information flow; (iv) Offer an appealing scheme to reduce the road accidents and (v) Inculcating interest to Police officers regarding to their responsibilities by strengthening existing knowledge (Azman \& Ah, 2020; PDRM, 2021).

Through the objectives of Salleh system, police officers are given the responsibility to operate and monitor neighbourhoods that have been classified as sectors. These police officers are also located in the sector where they are accountable to establish bond with the local communities and establish confidence within the community. Indirectly, the understanding and awareness among the police officers will enhance their efficiency towards ensuring the safety among locals. The system was tested for the first time in Petaling Jaya in February 1968 to see its effectiveness. This attempt proved to be effective and successful in reducing the crime rate in the Petaling Jaya area. On 7 June 1968 through the Royal Malaysia Police (PDRM) Force Order, instructions were issued to implement this system in all police contingents. The success of the Salleh System in curbing and controlling the crime cannot be denied. Seen from the aspect of the police's relationship with the public, the Salleh System also managed to create a situation where the public views the police as a friendly institution who provides help when necessary. The presence of strong police-public relationships will make it easier for the police to perform their duties as national peace and security officers. Based on the Salleh System, community monitoring activities are growing with various names used in line with the process of modernization of the country (Aslie \& Ibrahim, 1984).

PDRM's Five Year Strategic Plan (PS5T) 2007-2011 is designed to formulate a clear strategy and direction in addressing various crises and challenges faced. One of the main thrusts that have been identified in the PS5T PDRM 2007-2011 is "addressing the problem of rising crime and community concerns about crime". One of the projects that have been identified under this thrust is the Community Policing Program (PDRM, 2021). PDRM has also introduced the concept of Community Policing or community surveillance as a philosophy of PDRM in implementing crime prevention. The new philosophy of PDRM requires the police and the community to act together as partners in identifying and effectively addressing issues related to crime and social ills in the local area, especially in residential areas or neighbourhoods. The emergence of police department across the globe implementing Community Policing can be seen as a sign for improvement toward nation building, and it involves sharing their knowledge and expertise in crime prevention and managing crime in locality with the community (Sulaiman, et al., 2021).

The purpose of this study is to understand the knowledge $(K)$, attitude $(A)$, and practices $(P)$, or simply termed as KAP of community policing among the local communities in Malaysia. This is the first empirical study that analyse its level of KAP in Malaysian context. This study is important because the community policing has been practiced for so long where it has been culturally embedded across neighbourhoods. According to Azman (2020), community policing has long been a part of our life, and it's present in our community in the form of real surveillance measures like the neighbourhood watch, patrol systems, and COP partner (RAKAN COP). Substantially, it shows that community policing is very common among Malaysians. However, to date, no KAP study on community policing has been conducted. Community policing is a relatively simple concept and practice that emphasizes the importance of a strong bond and interactive engagement between the community and the police with a coordinated approach (Sulaiman et al., 2014). On the other hand, community 
policing is also a practice that attempts to bring communities and law enforcement together in order to co-create safety. By engaging community members as partners in attempts to make their communities better and safer places to live, community policing able to empowers citizens (Bayerl et al., 2017). Thus, to generate a better place to live, the concept of community policing is seen to be increasingly important. Therefore, it is vital to comprehend the KAP study concerning community policing where in the future, it could generally precede evaluation of its impact and consequently ensuring the sustainability of Community Policing.

\section{Literature Review}

"Police Omnipresence" is synonymous with the concept of crime prevention. However, the presence of the police alone as in the activities carried out by the police such as bits, patrols and sector systems cannot achieve success without the involvement of the community. The policing approach cannot focus on reactive action alone as society is now experiencing environmental change, population growth, educational polarity, advances in science and technology as well as the presence of more sophisticated and globally shaped crime. Following these social dynamics, like other developed countries, PDRM has also undergone a transformation by planning a more dynamic crime prevention concept (Azman \& Ah, 2020; PDRM, 2021).

The concept of community-oriented policing is highlighted as an effort to achieve enhanced level of security that can be sustained through community involvement. Community Policing has been practiced by several countries such as France (Mouhanna, 2009); Belgium (Smeets and Tange, 2009); Britain (Kalunta, 2009); United States of America (Barlow, 2009); and Australia (Casey and Pike, 2007). Community policing is a collaborative effort between police and communities to establish the community's needs and expectations and to work together to address and resolve community issues (Community Policing Consortium, 1994; Hess \& Wrobleski, 1997). Successful initiative by developed countries promotes the idea for Malaysia to implement. Yero et al. (2012) proposed that community policing in Malaysia demonstrates style of operation that promotes openness and flexibility between the police and local communities, which include foot patrol, neighbourhood watch and town meetings, and public education. Through community policing, the members of the neighbourhoods work together with the police officers to formulate strategies and policies, as well as implementing the programs on crime prevention in their communities. At the same time, the police can provide the locals with education and awareness concerning the important role of local people to prevent and control the crime rate. Therefore, the effectiveness of this crime prevention program is expected to fulfil the community's dream to live in a secure and peaceful, while reducing the degree of 'fear of crime' across the neighbourhood.

\section{Method}

Cluster sampling method were used to sample total of 359 respondents of community policing from the active states in Malaysia; namely, Johor, Sarawak, Penang, Selangor were randomly selected in the first stage. Three active community policing has been selected from each state, which then 30 members were randomly selected to represent each community. Selected community policing was then contacted for their permission and cooperation. A discussion has been held between researcher and selected community policing members regarding data collection. The data for this study were collected through self-administered questionnaire. Before filling the questionnaire, the respondents were briefed on the questions. Descriptive statistics such as frequency, percentage, mean, and standard deviation 
were used to fulfil the determine objectives. Inferential analyses such as the independent ttest and ANOVA were used to determine any differences between socio-demographic and variables. Pearson correlation was used to determine whether there was a relationship between variables. A set of questionnaires was adopted from previous research with the same KAP concept study by Ahamad \& Ariffin (2018) where the reliability of the questionnaires was conducted to show it is suitable and reliable and is reported below in Table 1. The questionnaire consists of four parts socio demographic, knowledge, attitude and practices of community policing members. The items of knowledge, attitude and practices were measured through five-point Likert scales, ranging from 1 representing "strongly disagree" to 5 representing "strongly agree."

\section{Results and Discussion}

Table 1 shows high reliability of KAP measures on community policing, where knowledge, attitude, and practices demonstrated high values of Cronbach alpha ranging from 0.75 to 0.91 . These reveal that items employed in this study possess high internal consistency, where each set of items are closely related as a group.

Table 1: Reliability test for KAP variables

\begin{tabular}{ll}
\hline KAP variable & Cronbach Alpha, $\alpha$ \\
\hline Knowledge on community policing & 0.912 \\
Attitude towards community policing & 0.868 \\
Practices related to community policing & 0.751 \\
& \\
\hline
\end{tabular}

Comparison of community policing knowledge, attitude, and practices between male and female are presented in Table 2. These findings are based on total number of samples $(N=$ 359) in four communities that are practicing the community policing. Mean scores are based on the Likert scale $1-5$, where 5 is the highest. It was found that male and female respondents scored from average-to-high for KAP variables. Both genders attained lower average levels of practices (Mean $=3.4$ and 3.8) compared to their knowledge and attitude that scored higher than 4.0. These findings are consistent with previous studies (Nde et al., 2015; Albarrak et al., 2019) where the levels of practices were persistently the lowest because people who attained high knowledge and attitude often find difficulties to practice what they know or sense. Furthermore, except for the attitude, this study found that male scored significantly $(p<0.01)$ higher that female in terms of knowledge and practices. However, the differences between male and female were larger for the practices (i.e., 0.41) compared to the knowledge (i.e., 0.22) on community policing. This implies that males are practicing greatly more than females. This could be due to the reason that men are engaging more in the protection of their neighbourhood compared to women, who are generally housewives (Kenea, 2019; Shen et al., 2017; Mäkelä et al., 2017). 
Table 2: Comparison of community-oriented policing knowledge, attitude, and practices between male and female through t-test.

\begin{tabular}{|c|c|c|c|c|c|}
\hline KAP variable & $n$ & Mean & SD & t value & sig. \\
\hline \multicolumn{6}{|l|}{ Knowledge on community policing } \\
\hline Male & 193 & 4.193 & 0.032 & \multirow{2}{*}{3.909} & \multirow{2}{*}{0.000} \\
\hline Female & 166 & 3.969 & 0.048 & & \\
\hline \multicolumn{6}{|l|}{ Attitude towards community policing } \\
\hline Male & 193 & 4.144 & 0.045 & \multirow{2}{*}{1.508} & \multirow{2}{*}{0.133} \\
\hline Female & 166 & 4.020 & 0.074 & & \\
\hline \multicolumn{6}{|l|}{$\begin{array}{l}\text { Practices related to community } \\
\text { policing }\end{array}$} \\
\hline Male & 193 & 3.784 & 0.061 & \multirow{2}{*}{3.831} & \multirow{2}{*}{0.000} \\
\hline Female & 166 & 3.373 & 0.089 & & \\
\hline
\end{tabular}

Furthermore, Table 3 demonstrated differences in KAP scores between people of high and low educational levels. Respondents with tertiary education had significantly greater knowledge on community policing than those without diplomas and bachelor's degrees. The very high t-value of 4.6 indicates that people with higher education tend to explore more on general knowledge about community policing they didn't learn through formal schooling. However, both attitude and practices seem not to be associated with individuals' level of education. Meanwhile, most of studies have proposed that translating knowledge and attitude into practices is very crucial in many aspects in life (Andersson et al., 2018; Ghani et al., 2019; Quimbo et al., 2018; Wong et al., 2015). Seeing that level of practices was not significantly related to tertiary education such as found in the current study, therefore it can be suggested that any policy implication on the community policing at national level can be generalized to local neighbourhoods without being bothered with their educational levels.

Table 3: Comparison of community-oriented policing knowledge, attitude, and practices between higher and lower educational levels through t-test.

\begin{tabular}{|c|c|c|c|c|c|}
\hline KAP variable & $n$ & Mean & SD & t value & sig. \\
\hline \multicolumn{6}{|l|}{ Knowledge on community policing } \\
\hline Tertiary education & 142 & 4.187 & 0.419 & \multirow{2}{*}{4.640} & \multirow{2}{*}{0.000} \\
\hline Primary or secondary education & 217 & 3.905 & 0.395 & & \\
\hline \multicolumn{6}{|c|}{ Attitude towards community policing } \\
\hline Tertiary education & 142 & 4.134 & 0.620 & \multirow{2}{*}{1.439} & \multirow{2}{*}{0.154} \\
\hline Primary or secondary education & 217 & 4.005 & 0.579 & & \\
\hline \multicolumn{6}{|c|}{$\begin{array}{l}\text { Practices related to community } \\
\text { policing }\end{array}$} \\
\hline Tertiary education & 142 & 3.690 & 0.859 & \multirow{2}{*}{1.444} & \multirow{2}{*}{0.150} \\
\hline Primary or secondary education & 217 & 3.516 & 0.675 & & \\
\hline
\end{tabular}

Moreover, this study compares the levels of knowledge, attitude, and practices according to three age categories using ANOVA. It was found that KAP scores were not significantly $(p>$ 
0.05) associated with the age group. However, this study has noticed some trends where younger generation scored higher on knowledge, while the older generation were more enhanced in their attitude and practices. Therefore, this study performed additional t-tests to compare between the young respondents (aged less than 30) and the older generation those aged 50 and above. Presented as Table 5, the t-tests revealed significant differences at $p<0.05$ levels between the two generations for the three KAP measures. Specifically, younger generation attained higher level of knowledge compared to the oldest group. In this case, it can be suggested that young individuals are more resourceful and thus are more up-to-date in term of knowledge on community policing. In contrast, scores on attitude and practices were significantly higher for those aged $\geq 50$ compared to respondents age $\leq 29$. These findings are consistent with some previous researchers (Babaei et al., 2012; Sulaiman et al., 2013; Murayama et al., 2015) who claimed that older generations have greater sense of belonging towards their neighbourhoods. Hence, it is not a surprise to discover that older people who aged above 50 spend more time and effort towards practicing on community policing compared to the young generation, as proved in this study.

Table 4: Comparison of community-oriented policing knowledge, attitude, and practices between different age groups through ANOVA.

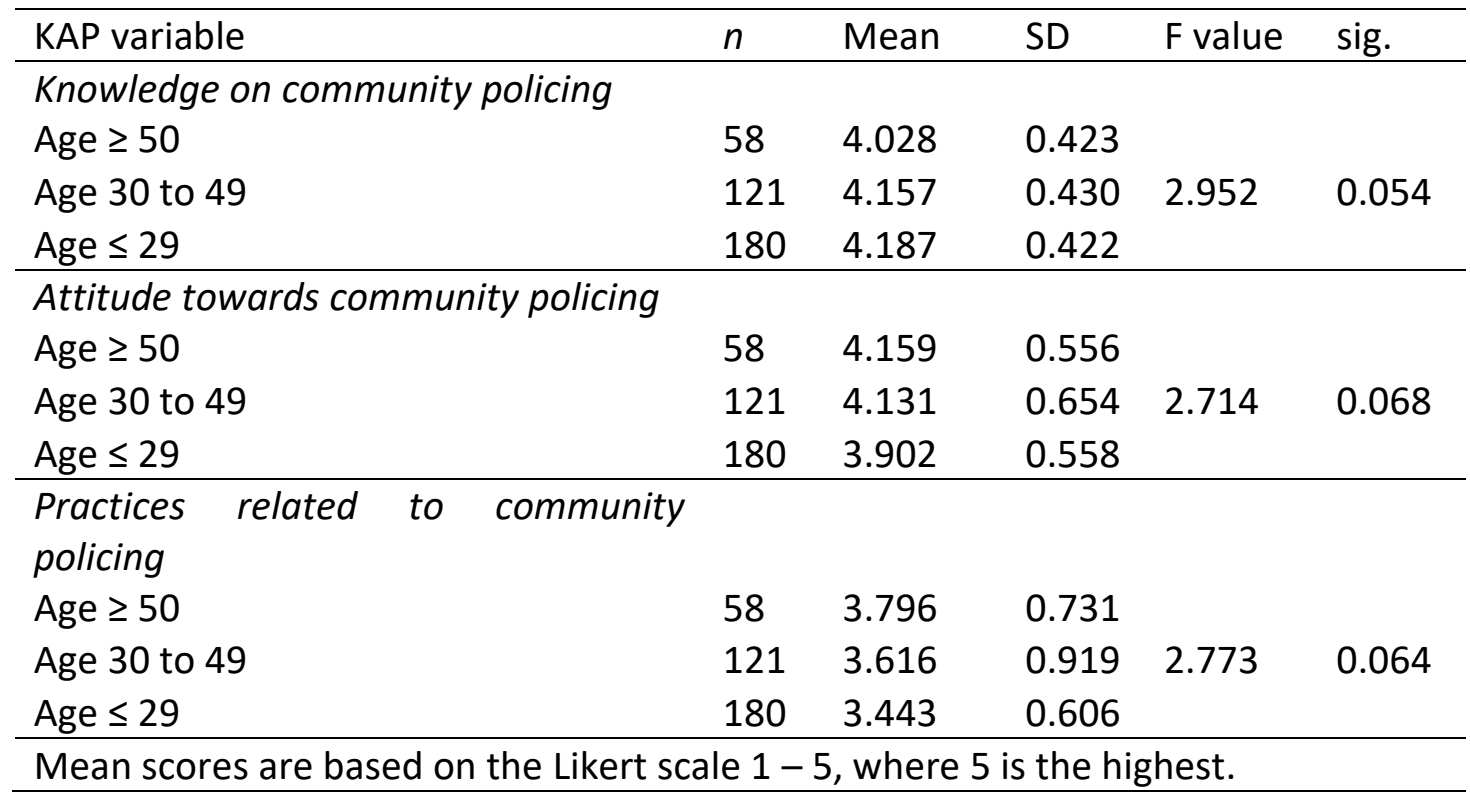


Table 5: Comparison of community-oriented policing knowledge, attitude, and practices between the oldest and youngest age groups through $\mathrm{t}$-test.

\begin{tabular}{|c|c|c|c|c|c|}
\hline KAP variable & $n$ & Mean & SD & t value & sig. \\
\hline \multicolumn{6}{|l|}{ Knowledge on community policing } \\
\hline Age $\geq 50$ & 58 & 4.028 & 0.423 & \multirow{2}{*}{2.114} & \multirow{2}{*}{0.037} \\
\hline Age $\leq 29$ & 180 & 4.187 & 0.422 & & \\
\hline \multicolumn{6}{|l|}{ Attitude towards community policing } \\
\hline Age $\geq 50$ & 58 & 4.159 & 0.556 & \multirow{2}{*}{2.319} & \multirow{2}{*}{0.023} \\
\hline Age $\leq 29$ & 180 & 3.902 & 0.558 & & \\
\hline \multicolumn{6}{|l|}{$\begin{array}{l}\text { Practices related to community } \\
\text { policing }\end{array}$} \\
\hline Age $\geq 50$ & 58 & 3.796 & 0.731 & \multirow{2}{*}{2.619} & \multirow{2}{*}{0.010} \\
\hline Age $\leq 29$ & 180 & 3.443 & 0.606 & & \\
\hline
\end{tabular}

Mean scores are based on the Likert scale $1-5$, where 5 is the highest.

Finally, Table 6 presents Pearson correlations between the KAP variables. Notably, relationships between all variables were positive. While all the correlations are significant at $1 \%$ level, this study found that the relationships of knowledge-attitude and attitude-practice are equally the highest $(r=0.48)$. On the other hand, the correlation between knowledge and practices are substantially low $(r=0.28)$ than the other two. This evidence shows that it is not effortless for people to transform the knowledge on community policing they had into practice.

Table 6: Correlations between community-oriented policing knowledge, attitude, and practice.

\begin{tabular}{llll}
\hline KAP variable & $(1)$ & $(2)$ & $(3)$ \\
\hline 1. Knowledge on community policing & 1.000 & & \\
2. Attitude towards community policing & $0.483^{* *}$ & 1.000 & \\
3. Practices related to community policing & $0.277^{* *}$ & $0.479^{* *}$ & 1.000 \\
\hline **Significant at the 0.01 level (2-tailed). & & & \\
\hline
\end{tabular}

\section{Conclusion}

The concept of community -oriented policing is emphasized as an effort to achieve a better level of protection and security that can be maintained through the involvement of community members in the neighbourhood. Seeing that it has been implemented for five decades, a basic study of KAP should be conducted to identify its level of knowledge, attitudes, and practices in the current context. Therefore, this study has demonstrated high levels of knowledge and attitude, and a moderate level of practice towards community policing in the current Malaysian context. Thus, it can be concluded that in general, the local communities have exercised community policing despite living in busy urban environments.

Based on these findings, it is appropriate to point out that the Ministry of National Unity Malaysia should integrate the concept of community-oriented policing as its focus agenda to promote social unity and social integration among Malaysians. Citizens who live in the same neighbourhood are integrated into their local ethnic or religious group. Community policing plays an important role to promote liveability, such as by improving people's sense of safety, 
and by advancing social cohesion by nurturing relations between different groups. Finally, it is proposed that the Royal Malaysia Police (PDRM) enhances the excellence of services among police officers, as well as the visibility and efficacy of their officials, especially when being responsible to the community or overcoming community problems. These strategies tend to strengthen the relationship between the police and the community, while fostering social cohesion and trust within the neighbourhood.

\section{Funding Declaration}

This work was supported by Universiti Putra Malaysia (GP-9582500).

\section{References}

Ahamad, N. R., \& Ariffin, M. (2018). Assessment of knowledge, attitude and practice towards sustainable consumption among university students in Selangor, Malaysia. Sustainable Production and Consumption, 16, 88-98.

Albarrak, A. I., Mohammed, R., Al Elayan, A., Al Fawaz, F., Al Masry, M., Al Shammari, M., \& Miaygil, S. B. (2019). Middle East Respiratory Syndrome (MERS): Comparing the knowledge, attitude and practices of different health care workers. Journal of Infection and Public Health, 14, 89-96.

Andersson, M., Wilde-Larsson, B., \& Persenius, M. (2018). Intensive care nurses fail to translate knowledge and skills into practice - A mixed-methods study on perceptions of oral care. Intensive and Critical Care Nursing, 52, 51-60.

Aslie, M. R., \& Ibrahim, M. R. (1984). Polis Diraja Malaysia: Sejarah, peranan, dan cabaran. Kuala Lumpur: Kumpulan Karangkraf.

Azman, Z., \& Ah, S. H. A. B. (2020). Konsep dan perkembangan program pengawasan komuniti di malaysia: the concept of community policing and its development in Malaysia. Sarjana, 35(1), 42-59.

Babaei, H., Ahmad, N., \& Gill, S. S. (2012). Bonding, bridging, and linking social capital and psychological empowerment among squatter settlements in Tehran, Iran. Journal of Basic and Applied Scientific Research, 2(3), 2639-2645.

Barlow, D. E., \& BARLOW, M. H. (2009). Community Policing in the United States: Social control through image management. In Community Policing (pp. 183-204). Routledge.

Bayerl, P. S., Karlović, R., Akhgar, B., \& Markarian, G. (2017). Community Policing-A European Perspective. Springer.

Casey, J., \& Pike, D. (2007). Fit for purpose: working with the community to strengthen policing in Victoria, Australia. Flinders Journal of Law Reform, 10(3), 373-401.

Ghani, N. A., Shohaimi, S., Hee, A. K. W., Chee, H. Y., Emmanuel, O., \& Ajibola, A. L. S. (2019). Comparison of knowledge, attitude, and practice among communities living in hotspot and non-hotspot areas of dengue in Selangor, Malaysia. Tropical Medicine and Infectious Disease, 4(1), 37.

Ismail, H., \& Muzium Polis Diraja Malaysia. (2004). Sejarah bergambar Institusi Polis di Malaysia. Kuala Lumpur: Institut Polis Malaysia.

Kalunta-Crumpton, A. (2009). Patterns of community policing in Britain. In Community Policing (pp. 165-182). Routledge.

Kenea, R. B. (2019). Research on the Assessment of Impacts of Gender Differences on Women's Participation in Community Work in Abbay Chomman Woreda, Ethiopia. International Journal of Management Studies and Social Science Research, 1(6), 11-26. 
Mäkelä, S., Aaltonen, S., Korhonen, T., Rose, R. J., \& Kaprio, J. (2017). Diversity of leisure-time sport activities in adolescence as a predictor of leisure-time physical activity in adulthood. Scandinavian Journal of Medicine \& Science in Sports, 27(12), 1902-1912.

Mouhanna, C. (2009). The French centralized model of policing: Control of the citizens. In Community Policing (pp. 119-140). Routledge.

Murayama, H., Nofuji, Y., Matsuo, E., Nishi, M., Taniguchi, Y., Fujiwara, Y., \& Shinkai, S. (2015). Are neighborhood bonding and bridging social capital protective against depressive mood in old age? A multilevel analysis in Japan. Social Science \& Medicine, 124, 171179.

Nde, F. P., Assob, J. C., Kwenti, T. E., Njunda, A. L., \& Tainenbe, T. R. (2015). Knowledge, attitude and practice of breast self-examination among female undergraduate students in the University of Buea. BMC Research Notes, 8(43), 1-6.

PDRM. (2011). Sistem Salleh. Polis Diraja Malaysia. Retrieved online at https://www.rmp.gov.my/infor-korporate/polis-diraja-malaysia/sejarah/sistem-salleh on August 26, 2021)

Quimbo, M. A. T., Perez, J. E. M., \& Tan, F. O. (2018). Community development approaches and methods: Implications for community development practice and research. Community Development, 49(5), 589-603.

Shen, T., Teo, T. Y., Yap, J. J., \& Yeo, K. K. (2017). Gender differences in knowledge, attitudes and practices towards cardiovascular disease and its treatment among Asian patients. ANNALS Academy of Medicine Singapore, 46, 20-28.

Smeets, S., \& Tange, C. (2009). Community policing in Belgium: The vicissitudes of the development of a police model. In Community Policing (pp. 141-164). Routledge.

Sulaiman, A. H., Othman, J., Samah, B. A., Yero, A., D'Silva, J. L., \& Ortega, A. (2014). Determinants of community participation in community policing program in Malaysia. Journal of Applied Sciences, 14(20), 2439-2449.

Sulaiman, A. H., Hamsan, H. H., Yero, A., \& Lawrence, J. (2021). Police Officer's Commitment towards Community Policing in Malaysia: Instruments Development and Validation. International Journal of Academic Research in Business and Social Sciences, 11(15), 245261.

Wong, L. P., Shakir, S. M. M., Atefi, N., \& AbuBakar, S. (2015). Factors affecting dengue prevention practices: nationwide survey of the Malaysian public. PloS One, 10(4), e0122890.

Yero, A., Othman, J., Samah, B. A., D'Silva, J. L., \& Sulaiman, A. H. (2012). Re-visiting concept and theories of community policing. International Journal of Academic Research, 4(4), 51-55. 